胆囊ポリープ様病変の超音波診断とその手術適応

\begin{tabular}{|c|c|c|c|c|}
\hline \multicolumn{5}{|c|}{ 聖マリアンナ医科大学第 1 外科 } \\
\hline 山口 & 晋 & 大山 & 猪狩 & 次郎 \\
\hline 栗原 & 肇 & 生田目公夫 & 得平 & 卓主 \\
\hline 萩原 & 優 & 福田 & 渡辺 & \\
\hline
\end{tabular}

\title{
ULTRASONIC DIAGNOSIS AND OPERATIVE INDICATION OF POLYPOID LESIONS OF THE GALLBLADDER
}

\author{
Susumu YAMAGUCHI, Izumi OHYAMA, Jirou IKARI, \\ Hajime KURIHARA, Kimio NAMATAME, Takuhiko EHIRA, \\ Masaru HAGIWARA, Mamoru FUKUDA and Hiromu WATANABE \\ 1st Department of Surgermy, St. Marianna University School of Medicine
}

\begin{abstract}
超音波断層法の進歩によって，胆輷ポリープ様病変が発見される機会が増加してきた，胆霊ポリー プ様病変の手術適応についてはいまだ意見の統一をみない，そこで, 胆虂ポリープ様病変を検討し, その手術適応について考察した。

私と゚もが経験した胆虽ポリープ様病变を有する摘出胆衰は13例であり, 胆裏コレステロールポリー プが 8 例と最も多く, 胆震癌 3 例, 腺腫, 炎症性肉芽腫各 1 例であった。

胆囊コレステロールポリープの多くは $10 \mathrm{~mm}$ 以下で有茎性であり, 胆霊癌の多くは $10 \mathrm{~mm}$ 以上で広 基性であった。従って, 胆襄ポリープ様病変に対する手術適応は胆摘術を原則とするが, $10 \mathrm{~mm}$ 以上 のもの，広基性のもの，50歳以上のものには積極的に手術を行うべきと思われた。
\end{abstract}

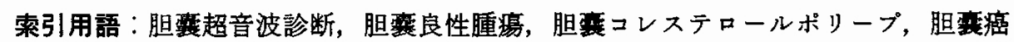

はじめに

従来, 胆道造影に拁いて胆豊が描出されない場合に は, 胆譱内病変の診断が困難であった。 しかし, 近年, 超音波検査法の進歩によって, 胆袈内病変の診断がか なり容易になり，胆囊内結石の診断率は $100 \%$ に近く， また，組織学的診断には限界があるものの，胆䪄壁の 病変の把握がかなり可能となってきた。その結果, 早 期の胆囊癌が発見される機会が増加している. 同時に

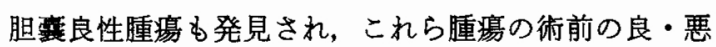
性の鑑別，手術適応が問題となっている。

今回, 私どすが摘出胆桽に㧹いて確認した胆囊ポ リープ様病変に関して，超音波検查所見を中心に臨床 的事項を含め検討し, 超音波検查にて診断されたポ リープ様病変の良・悪性の鑑別, 手術適応について考

$<1984$ 年11月21日受理 $>$ 別刷請求先：山口 晋 下213 川崎市宮前区营生2095 聖マリアンナ医科大 学第 1 外科
察した。

\section{対象}

昭和 49 年 2 月から昭和 58 年 12 月の間に摘出され，か つ, 超音波検査が行われたポリープ様病変を有する症 例は13例である，その内訳はュレステロールポリープ 8 例, 腺腫 1 例, 炎症性肉芽腫 1 例括よび胆霊癌 3 例 である(表 1 )。また，同期間中に経験した胆囊癌症例 はこの 3 例を含めて 22 例あり，良性腫瘍の発病年龄々 の比較の対象とした。

\section{結 果}

胆哓ポリープ様病変13例の中ではコレステロールポ リープが 8 例ともっとも多く, 年齢は28歳から 46 歳ま でで, 平均年齢は39.7歳であった. 性別では男 6 例, 女 2 例と男に多くみられた。コレステロールポリープ

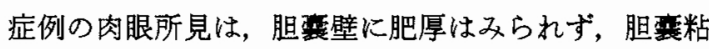
膜はよく温存されていた。ポリープの大きさは $2 \mathrm{~mm}$ ら $10 \mathrm{~mm}$ までで, 発生数は 1 個のものは 1 例で, 他の 
表 1 胆囊ポリープ様病変を伴ら症例

\begin{tabular}{|c|c|c|c|c|c|c|c|c|}
\hline \multicolumn{2}{|c|}{ 症 例 } & 年柃 & 性 & 主 訴 & 肝機能 & 胆裹造影 & 超音波所見 & 確 定 䛦 断 \\
\hline 1 & H. T. & 39 & 男 & $(-)$ & 正常 & $P(+)$ & $P(+)$ & コレステロールポリープ \\
\hline 2 & I. K. & 42 & 男 & 心窩部痛 & "1 & " & " & " \\
\hline 3 & Y.S. & 28 & 男 & 右季肋部痛 & " & $\mathrm{P}(+) \cdot \mathrm{St}(+)$ & $\mathrm{P}(+) \cdot \mathrm{St}(+)$ & ", 結 石 \\
\hline 4 & W. S. & 37 & 男 & $" 1$ & " & $P(t)$ & $\mathrm{P}(+)$ & コレステロールポリープ \\
\hline 5 & S. M. & 36 & 女 & $(-)$ & "1 & " & " & " \\
\hline 6 & E. K. & 37 & 男 & 右季肋部痛 & " & "I & $" \prime$ & " \\
\hline 7 & H. T. & 45 & 男 & " & 異常 & $\mathrm{P}(-)$ & " & " \\
\hline 8 & T. S. & 46 & 女 & $"$ & 正常 & $P(+)$ & $"$ & ", 結 \\
\hline 9 & I. M. & 42 & 男 & $(-)$ & " & " & " & 腺腫 \\
\hline 10 & Y. Y. & 50 & 男 & 右季肋部痛 & 異常 & 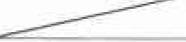 & "I & 炎症性肉芽腫 \\
\hline 11 & H. R. & 53 & 女 & 心窩部痛 & 正常 & 造影不能 & $P(+) \cdot S t(+)$ & 癌, 結 石 \\
\hline 12 & S. U. & 63 & 女 & 右季肋部痛 & " & 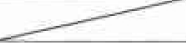 & $\mathrm{P}(-) \cdot \mathrm{St}(+)$ & $" 1$ \\
\hline 13 & T. H. & 73 & 女 & 黄 瘨 & 異常 & $\mathbf{P}(+)^{*}$ & $P(+)$ & " , 胆管癌 \\
\hline
\end{tabular}

(注) $\mathrm{P}$ ：ポリープ様病变像, St：結石像, * ERCによる. 他の症例はDIC

表 2 コレステロールポリープの性状

\begin{tabular}{c|c|c|c|c|c|c}
\hline \multicolumn{2}{c|}{ 症 例 } & 存在部位 & 形状 & 大きさ & 個数 & エコーレベル \\
\hline 1 & H. T. & 底 部 & 有茎 & $\sim 6 \mathrm{~mm}$ & 2 & 強 \\
\hline 2 & I. K. & 頝 部 & " & $\sim 5$ & 多発 & " \\
\hline 3 & Y.S. & 底 部 & " & 10 & 1 & 中 \\
\hline 4 & W. S. & 頝・体部 & " & $\sim 5$ & 多発 & " \\
\hline 5 & S. M. & " & " & $\sim 6$ & 3 & 強 \\
\hline 6 & E. K. & 全 体 & " & $\sim 3$ & 多発 & 中 \\
\hline 7 & H. T. & 体・底部 & " & $\sim 3$ & " & 強 \\
\hline 8 & T. S. & 体 部 & " & $\sim 4$ & " & " \\
\hline
\end{tabular}

症例は多発例であった(表 2 )。発生部位に特に好発部 位はなかった。これらのポリープ症例は超音波検查に て描出され，超音波像は胆囊壁に隆起する胆囊壁と同 等ないし濃い濃度で，音響陰影はみられなかった（図 1,2 ). 臨床症状は腹痛を伴うもの 6 例で, その内 2 例は胆石を合併していた。 また，無症状のものは 2 例 で胆石の合併はなかった，胆囊造影ではすべての症例 で胆䒼が造影され, 胆囊の収縮能も認められ, その内, 7 例にポリープの透亮像がみられた。肝機能検查成績 は肝硬変を合併した症例 7 の 1 例のみが異常であっ た。

腺腫の症例 9 は42歳男で, 症状はなく, 肝機能検査 成績は正常であった，腺腫は大きさ $11 \mathrm{~mm}$ であり，超 音波検査にて頝部に音響陰影を伴わない均一な球状の 像として胆霟壁に接してみられた(図3). 胆囊造影で
は胆囊は造影され，腺腫は透亮像としてみられた。 症例10は50歳男の肝細胞癌の症例にみられた胆囊壁 の炎症性肉芽腫とそれに附着したビリルビン塊であっ たが，起音波検査では胆囊内腔に隆起する不整形の病 変で, 胆囊癌と診断された(図 4 ). 右季肋部痛があり, 肝機能検查成績は異常を示した。

胆囊癌は症例 $11,12,1303$ 例で，全例女性で，年 齢は53歳, 63歳，73歳であった。症例11は胆豪内結石 の診断にて胆摘術を行ったものであるが, 摘出胆囊で は粘膜面に多数の扁平な結節状の隆起がみられた（図 5 a). 術前超音波検査では胆䯧壁の異常を見逃してい たが，粘膜面にわずかな不整像がみられた（図５ｂ）. 症例12は右季肋部痛が著明で, 急性胆襄炎として緊急 手術を行った，術前超音波検查では胆石は証明された が, 胆囊のポリープ様病変は認められなかった。摘出 標本では胆袈底部に扁平な結節状の $7 \mathrm{~mm}$ の隆起珄病 変として胆霊癌がみられた。また, 症例13は胆裹癌を 合併し黄疸を認めた。超音波検査では胆変内に明らか なポリープ様病変がみられ，摘出胆囊に結節状の隆起 として胆囊癌が認められた(図6). 以上ポリープ様病 変を呈した胆囊癌 3 例の病変の形状は無茥性の結節性 の隆起であった（表 3 ）。

\section{考察}

胆囊の真珄腫瘍には癌, 腺腫, 乳頭腫などがあり, 腫瘍性病変にはコレステロールポリープ, 腺筋腫症, 過形成, 肉芽腫などがある12). その中で良性病変では コレステロールポリープの割合が高く, ポリープ状の 
図 1 症例 4.多発性のコレステロールポリープ
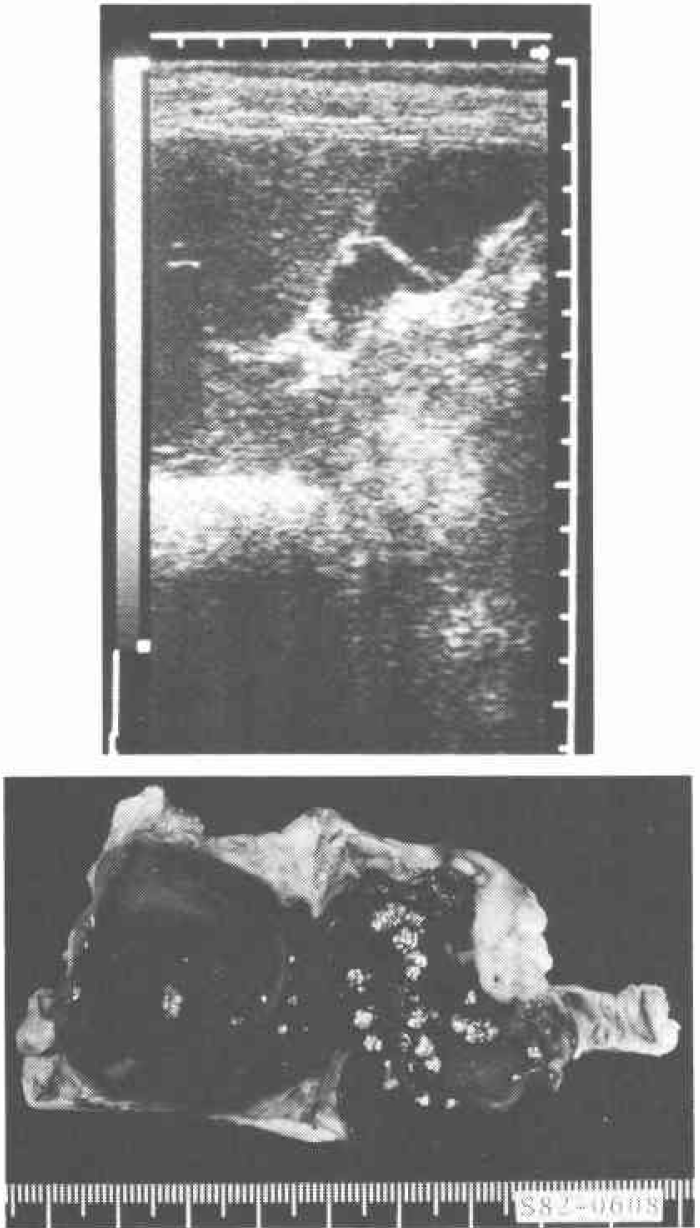

癌との鑑別が要求される、著者らの経験したポリープ 様病変を有する胆囊13例中 8 例がコレステロールポ リープであり，3 例が癌で, 諸家の報告と同様の傾向 であっだ)4.

〈コレステロールポリープ〉

コレステロールポリープは大ささは $10 \mathrm{~mm}$ 以下で 1 個のものから多数のものまであったが，諸家の報告で も多発性のものが多く，また，大ささは $10 \mathrm{~mm}$ 以上の ものはきわめて少ない(3) 5).コレステロールポリープ の形態は細い茎を有しており，体位変換により粘膜か らわずかに浮遊し, 摇れ動く場合があり参考になる. コレステロールポリープを有する胆囊では壁の炎症性 変化はほとんどなく，壁の肥厚は認められないことが 多い.ポリープのェコーレベルは胆囊壁よりも高いも のが多く, 大きなものでは写真7のごとく点状陰影の
図 2 症例 7. 胆囊コレステローシスに合併した多発 泩のコレステロールポリープ
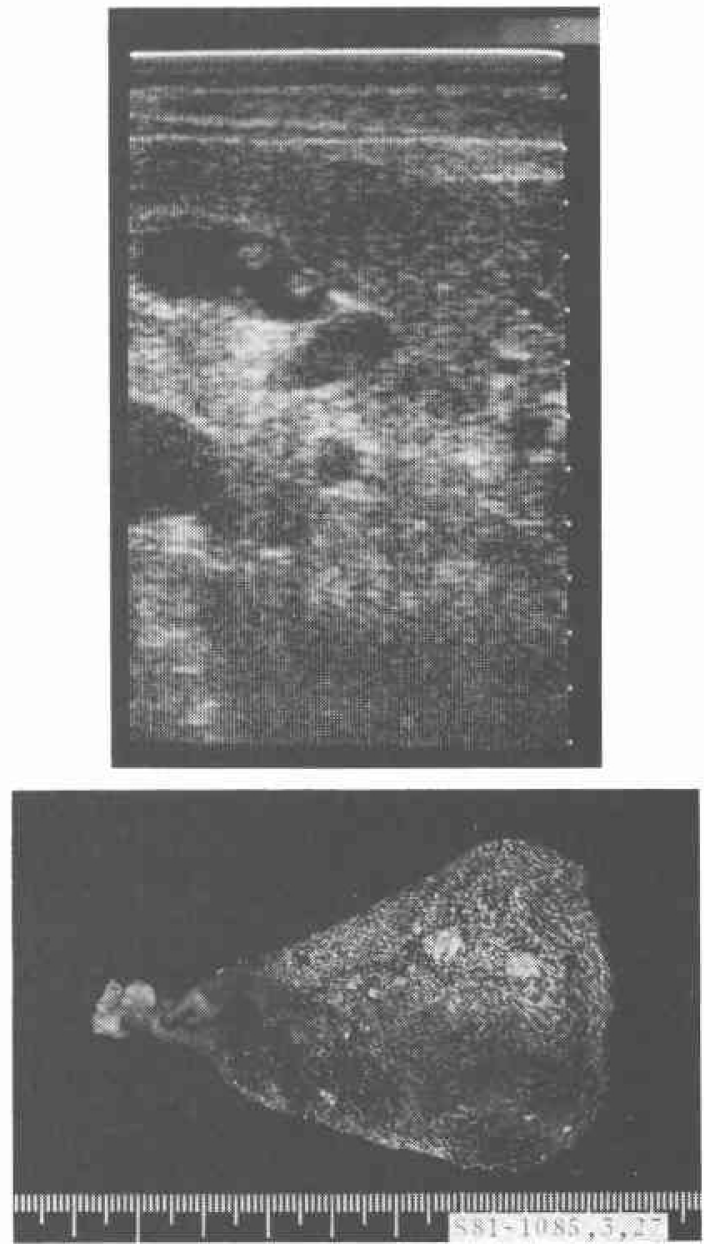

集合像としてみられる9.

コレステロールポリープの診断には他の臨床的所見 も参考になる。症状は合併する胆石によるものもある が,ポリープのみの症例でも疼痛を認めるものむある. しかし, 症状は一般に軽度であり, 無症状のものも多 い. 肝機能検査成績はほとんど正常である，胆囊造彰 では胆囊は造影されることが多く, 収縮能が認められ， 注意深い観察によって，その中にポリープによる透克 像をみるものが多い.

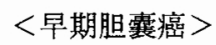

早期胆囊癌の定義はいまだ結論が出でいないが，粘 膜下層までにとどまる $\mathrm{m}$ 癌とするものと, 固有筋層ま

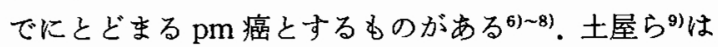
胆霊癌の超音波像を限局腫瘤型, 壁不整肥厚型, 全体 
図 3 症例 9 , 腺腫
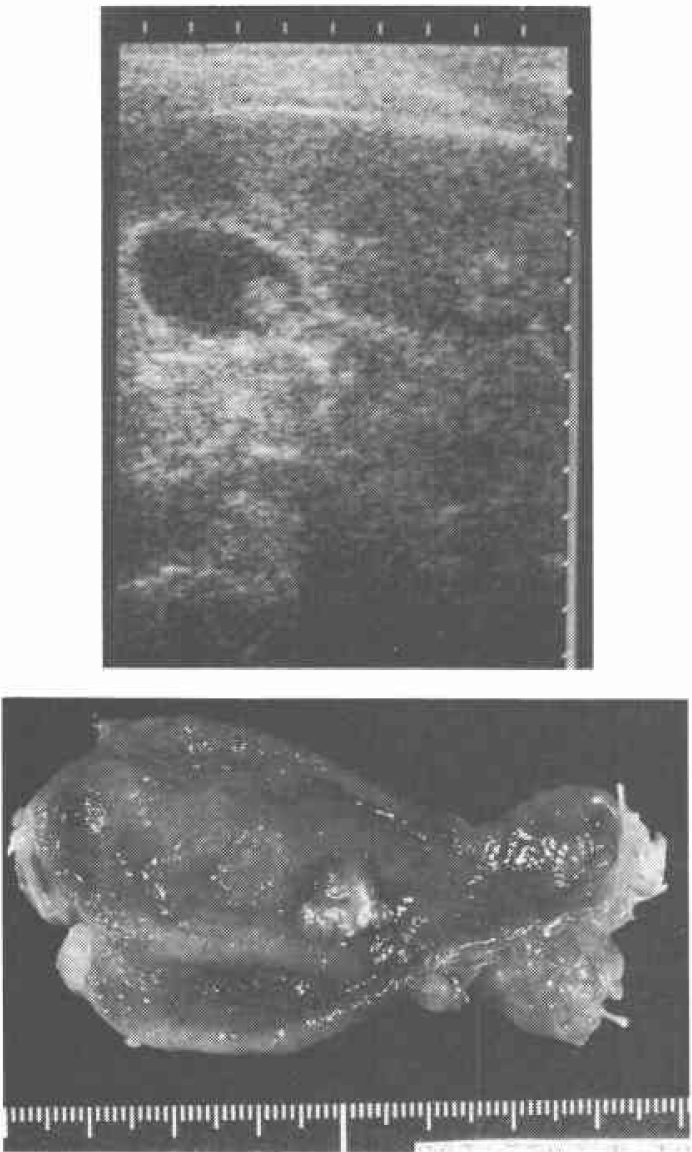

図 4 症例10. 炎症性肉芽腫

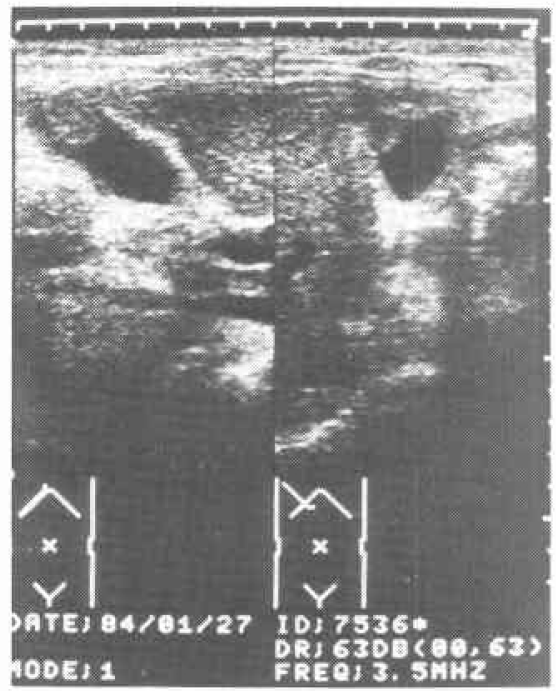

図 $5 \mathrm{a}$ 症例11. 胆糞癌, 結節状の隆起性病変が多発し ている.
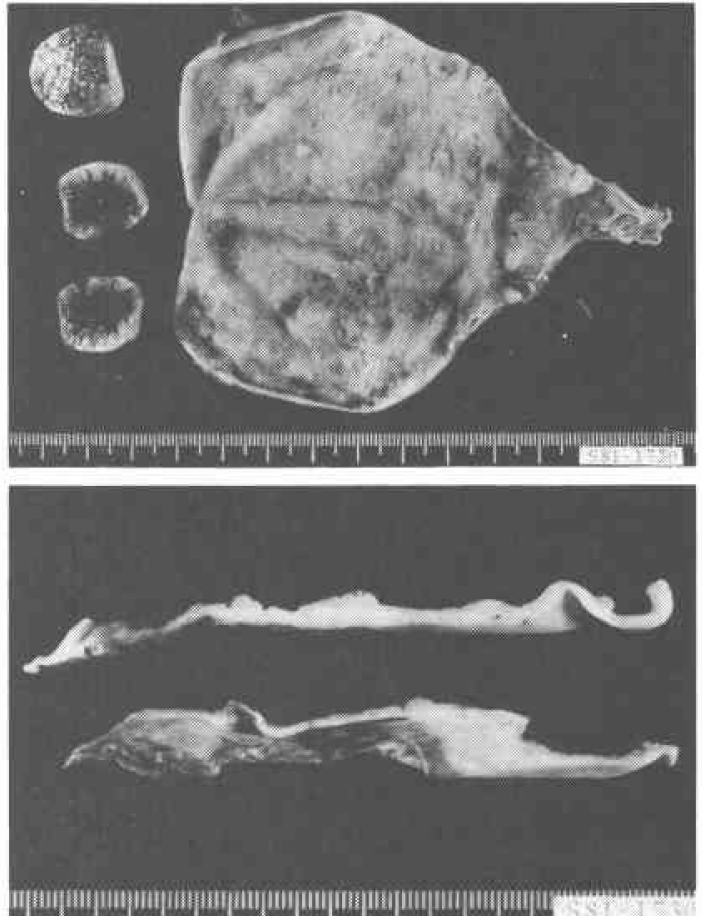

図 $5 \mathrm{~b}$ 胆囊壁に結節状の隆起がみられる. 胆石を合 併している.

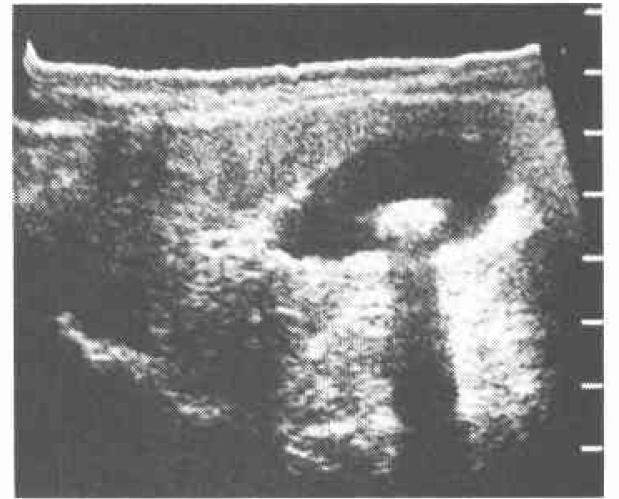

腫瘤型に分類しているが，その中で限局腫瘤型22例中 13例が Stage I の早期例であり，ことに $13 \mathrm{~mm}$ 末満の 小隆起型に良好な予後が期待されるという。 pm癌ま でにとどまる早期癌の形態は富士らうの報告によると $\mathrm{m}$ 癌54例中48例 (92\%), pm 癌31例中23例 (79\%) が隆 起型であり，隆起性病変の発見は早期癌の発見につな がるという。 
図 6 症例13. 胆衰癌, 頝部と底部に結節状の隆起性 病変がみられる.
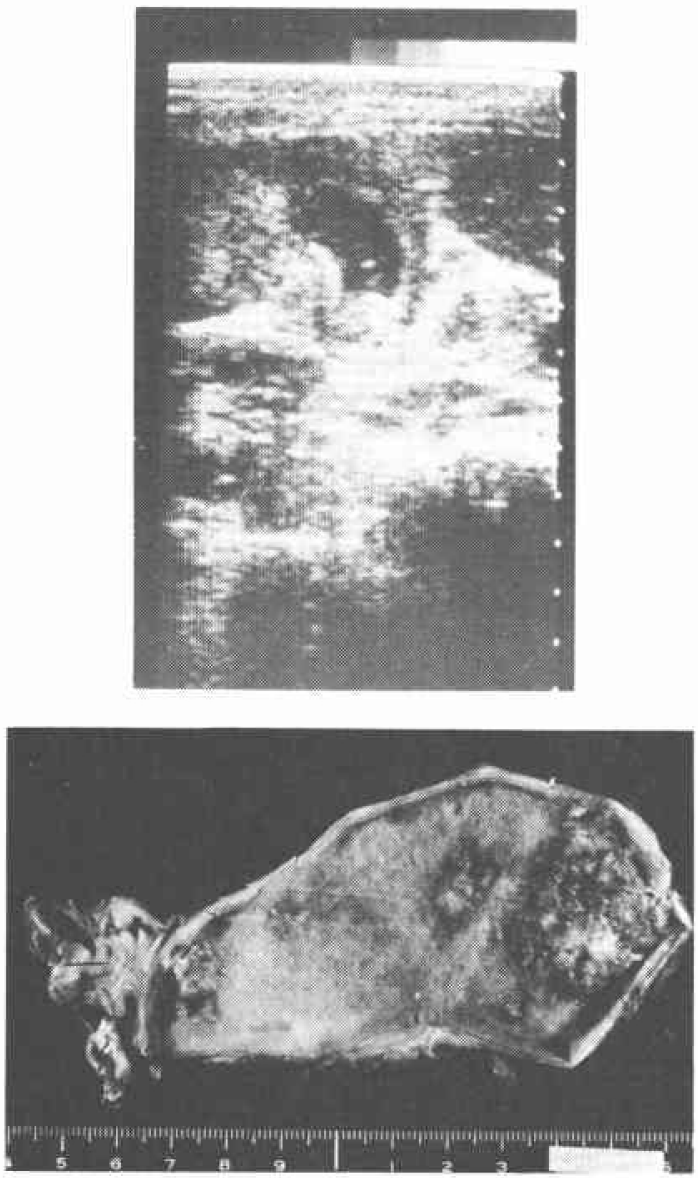

表 3 胆霅癌（ポリープ様病変）の性状

\begin{tabular}{c|c|c|c|c|c|c}
\hline \multicolumn{2}{c|}{ 症 例 } & 存在部位 & 形状 & 大きさ & 個数 & エューレベル \\
\hline 11 & H. R. & 全体 & 無茎 & $\sim 11 \mathrm{~mm}$ & 多数 & 強 \\
\hline 12 & S. U. & 底部 & " & $7 \mathrm{~mm}$ & 1 & 不明 \\
\hline 13 & T. H. & 底・頝部 & " & $\sim 36 \mathrm{~mm}$ & 4 & 中 \\
\hline
\end{tabular}

隆起性病変の良・悪性の鑑別にはその大きさが参考 になる. 別拊ら5よると, コレステロールポリープ15 例, 腺腫 7 例に $10 \mathrm{~mm}$ を超えた症例はなく, $10 \mathrm{~mm}$ 以 上の大きさを有した隆起性病変の寸べてが胆囊癌で あった。土屋ら ${ }^{9}$ の報告では $13 \mathrm{~mm}$ 以上の隆起性病変 はすべて胆囊癌であった。しかし，それ以下の中に胆 震癌が存在する場合があり, 注意すべさである(5)7 9). 著者らの症例でも症例 12 ごとく $7 \mathrm{~mm}$ の結節状の病 変が胆暴癌であった。
図 7 症例 3. 胆蘘コレステローシスに合併した比較 的大きなコレステロールポリープ
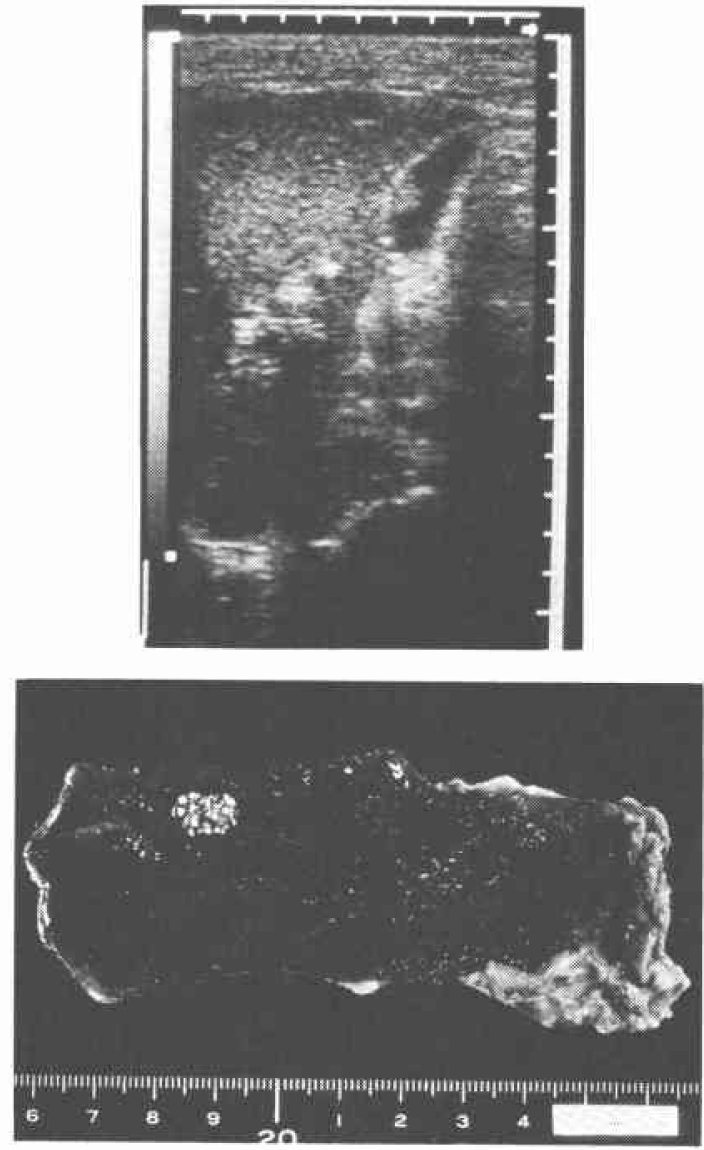

表 4 良性ポリープ様病変と胆囊癌症例の年齢

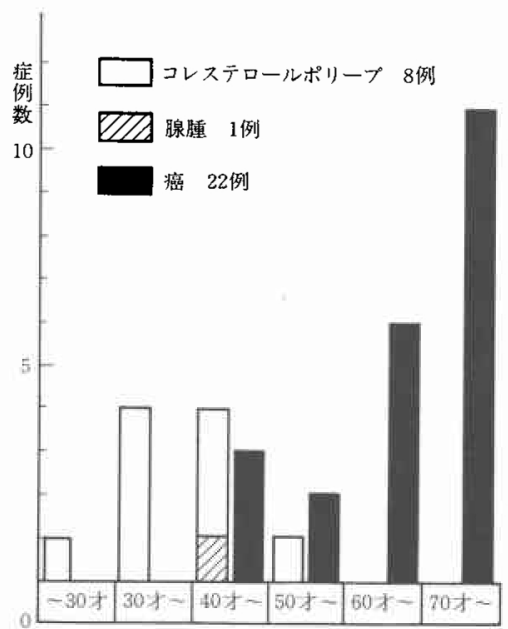


早期胆亳癌の隆起性病変の形態は有茎性や広基性が あり一定しないが, 癌診断の参考所見として, 厷基性 があること，ポリープが大きいこと，表面が結節性で あることがあげられている(5)10)．著者らの胆囊癌 3 例 はいずれも広基性で結節型であった。乳頭漫潤型や結 節浸潤型では壁の肥厚を合併しており，超音波像でも 壁の状態の観察が必要である ${ }^{10)}$.

〈胆囊ポリープ様病変の治療方針＞

良性腫瘍や腫瘍性病変でも結石合併例や症状を有す るものは手術適応があるが，絶対的手術適応とはなら ない，逆に，胆䉴癌ではリンパ節郭清を含めた抎大手 術を行ら必要があることより，さらに検査をすすめ 良・悪性の確定診断がなされることが望ましい，CT scan や血管造影などの画像診断む有用であるが, 胆襄 ポリープ様病変の確定診断には限界がある。経皮経肝 的胆䨢穿刺による細胞診，あるいは経皮経肝的胆囊内 視鏡による肉眼的観察および生検が確実な診断法であ ク，これらの検查法を積極的に行らものもある。しか し，多数発見されるポリープ様病変を有するすべての 症例に行らには癌細胞の散布やその他の合併症の問題 もあり，症例を選んで行うべきであろう。また，胆汁 中の CEA の測定の価値も報告されているが，比較的 早期の胆襄癌の診断には必ずしも有効ではない22. 従って，隆起珄病変の大きさから手術適応を決めると するものも多く, 田口ら ${ }^{8)} 0$ は $5 \mathrm{~mm}$ は経過観察, 6〜10 $\mathrm{mm}$ は手術が望をしいとし, $10 \mathrm{~mm}$ 以上の病変は 積極的な手術適応と結論している， ほ注同様の意見を 述べるものも多く，著者らも同様の方針で手術適応を 決めている45)9915). しかし，コレステロールポリープの 症例で胆震癌を合併したもの ${ }^{5}$ ，あるいは腺腫の一部 に癌病巣を合併した症例の報告があり ${ }^{11)}$ ，腺腫や乳頭 腫では悪性化の可能性が高いことを指摘するものもあ ク, 注意する必要がある213114).

胆露内隆起性病変の良・悪性の鑑別診断に年齢を参 考にすることも必要である，著者らの経験したコレス テロールポリープ, 腺腫の症例の年齢は 28 歳 46 歳に 対し, 胆囊癌は進行例も含めて22例では41歳 21 歳(平 均 61.9 歳) であり, 明らかに胆慗癌は50歳以上に多く みられ，50歳以上の隆起性病変は胆囊癌の可能性が高 く，積極的に手術を行うべきである.

摘出された胆囊の隆起性病变の肉眼的観察は欠かせ ないが，必ずしも良・悪性の鑑別が容易でない場合も あり，術中迅速病理組織診断が重要である。

\section{おわりに}

胆震摘出症例中13例飞胆豪ポリープ様病变を認め た．そのらち、コレステロールポリープが 8 例ともっ とも多く，ポリープの大きさは $10 \mathrm{~mm}$ 以下で，多発例 が 7 例にみられた。

他の症例は胆囊癌 3 例，腺腫，炎症性肉芽腫各 1 例 であった，腺腫以外は結節状隆起を呈した。

超音波断層像にみられるポリープ様病変の良・悪性 の鑑別は必ずしも容易ではない，手術適応に関しては 胆摘術を原則とするが，広基性のもの，10 $\mathrm{mm}$ 以上の もの，50歳以上のものには積極的に手術を行ら方針と したい.

\section{文献}

1) Christensen $A H$, Ishak $K G$ : Benign tumors and pseudotumors of the gallbladder : Report of 180 cases. Arch Pathol $90: 423-432,1970$

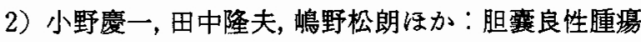
の問題一胆囊乳嘴腫を中心として。外科 35 ： 887-891, 1973

3）大和田康夫, 小山研二, 面川 進注か：胆震ポリー プ様病変の臨床病理.外科 $45: 1499-1506,1983$

4）河村良寛, 澄川 学, 河野菊弘流か：胆裹隆起性病 变の検討一特に超音波診断を中心として。外科診 療 $26: 1173-1177,1984$

5）別府倫兄, 万代恭嗣，伊藤徹ほか：胆衰の Polypoid lesionどのように検查をすすめ，手術 適応を決定するか。外科 $45: 1488-1493,1983$

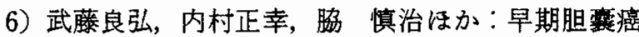
一その形態について。癌の臨 $26: 1665-1672$, 1980

7) 富士 匡, 河村 清水道彦ほか：早期胆哀癌 3 症例の診断過程と本邦報告例による $\mathrm{m}$ 癌と $\mathrm{pm}$ 癌の対比。胆と腪 $1: 1057-1064 ， 1980$

8）田口忠彦, 浦上育典, 庄 達夫ほか：胆襄内隆起性 病変の検討一早期胆震癌の 4 例括よび全国集計. 胆と苏 $5: 901-908,1984$

9）土屋幸治, 大藤正雄, 木村邦夫ほか：胆囊癌早期診 断の実際。胆之膵 $4: 1193-1201 ， 1983$

10）鳥塚莞爾，小島輝男，光野重根ほか：胆票癌の鑑別 ならびに進展度診断一US, CT の立場より。胆と 膵 $4: 1221-1226,1983$

11）吉田 隽, 山口 晋, 柿木千昌ほか：悪性変化を伴 5胆衰腺腫性ポリープの 1 例. 外科 $34: 1094$ $-1097,1972$

12）渡辺栄二：超音波断層法による胆重癌診断に関寸 る臨床的研究一とくに早期猃断能について，日消 外会誌 $16: 1684-1693,1983$

13）伊東敬之, 西井三徳, 子日光雄浮か：胆襄内隆起性 
病変の超音波診断とその手術適応一胆票早期癌発 見の approach として，胆と胼 4:1135-1142， 1983

14）荒木 攻，田原栄一：胆震におりる乳頭状腺腫に 発生した早期癌の 1 自呀例. 癌の臨 $21: 220$
-229, 1975

15）権藤守男, 霞富士雄, 草間 秀ほか：胆票隆起性病 変の超音波診断. 日超音波医会40回研発表会講論 集, 1982,p63-64 